\author{
Mariame El Messal · Karima Aït Chihab \\ Rachid Chater · Joan Carles Vallvé · Faïza Bennis \\ Aïcha Hafidi · Josep Ribalta · Mathilde Varret \\ Mohammed Loutfi · Jean Pierre Rabès · Anass Kettani \\ Catherine Boileau $\cdot$ Luis Masana $\cdot$ Ahmed Adlouni
}

\title{
Familial hypercholesterolemia in Morocco: first report of mutations in the LDL receptor gene
}

Received: 6 January 2003/ Accepted: 16 February 2003 / Published online: 18 March 2003

(C) The Japan Society of Human Genetics and Springer-Verlag 2003

\begin{abstract}
Familial hypercholesterolemia (FH) is a genetic disorder mainly caused by defects in the low-density lipoprotein receptor (LDLR) gene, although it can also be due to alterations in the gene encoding apolipoprotein B (familial defective apoB or FDB) or in other unidentified genes. In Morocco, the molecular basis of FH is unknown. To obtain information on this issue, 27 patients with $\mathrm{FH}$ from eight unrelated families were analyzed by screening the LDLR (PCR-SSCP and Southern blot) and apoB genes (PCR and restriction enzyme digestion analysis). None of the patients carried either the R3500Q or the R3531C mutation in the apoB gene. By contrast, seven mutations in the LDLR gene were identified, including five missense mutations on exons 4, 6, 8, and 14 (C113R, G266C, A370T, P664L,
\end{abstract}

M. El Messal $(\square) \cdot$ F. Bennis · M. Loutfi

Laboratoire de Biochimie,

Faculté des Sciences Aïn Chock, $\mathrm{Km} 8$,

Route d'El Jadida, BP 5366, Maarif, Casablanca, Morocco

E-mail: urlamaroc@hotmail.com

Tel.: + 212-22-230680 or + 212-22-230684

Fax: + 212-22-230674

K. Aït Chihab - R. Chater · A. Kettani - A. Adlouni Laboratoire de Recherche sur les Lipoprotéines,

Faculté des Sciences Ben M'Sik,

Casablanca, Morocco

J. C. Vallvé · J. Ribalta · L. Masana

URL, Facultad de Medicina,

Universidad Rovira I Virgili,

Reus, Spain

A. Hafidi

Service de Diabétologie et de Maladies Métaboliques, CHU Ibn Sina, Rabat, Morocco

M. Varret · J. P. Rabès $\cdot$ C. Boileau

INSERM U383, Hôpital Necker-Enfants Malades,

Paris, France

J. P. Rabès · C. Boileau

Laboratoire de Biochimie et de Génétique Moléculaire,

Hôpital A. Paré, Boulogne, France
C690S) and two large deletions (FH Morocco- 1 and $\mathrm{FH}$ Morocco-2). The two major rearrangements and the missense mutation $\mathrm{G} 266 \mathrm{C}$ are novel mutations and could well be causative of FH in the Moroccan population. This study has yielded preliminary information on the mutation spectrum of the LDLR gene among patients with FH in Morocco.

Keywords Familial hypercholesterolemia Low-density lipoprotein receptor gene · Apolipoprotein B gene ·

DNA sequencing $\cdot$ Single-strand conformation

polymorphism $\cdot$ Southern blot $\cdot$ Morocco

\section{Introduction}

Familial hypercholesterolemia $(\mathrm{FH})$ is a common autosomal dominant disease associated with elevated lowdensity lipoprotein (LDL) plasma cholesterol, tendon xanthomatosis, and premature atherosclerosis. The disorder of lipid metabolism in FH is mainly caused by defects in the LDL receptor (LDLR) gene (Goldstein et al. 1995), although it may also be due to alterations in the gene encoding apolipoprotein B (familial defective apoB or FDB) (Soria et al. 1989) or in other unidentified genes (Haddad et al. 1999; Norman et al. 1999; Varret et al. 1999; Hunt et al. 2000).

To date, more than 600 mutations have been described in the LDLR gene (Varret et al. 1998; Heath et al. 2001; databases are accessible at http// www.umd.necker.fr and http//www.ucl.ac.uk/fh). For the apoB gene, only four mutations have been shown to cause FDB: the most frequent is R3500Q (Myant 1993; Leren et al. 1997) and the very rare are R3500W (Gaffney et al. 1995), R3531C (Pullinger et al. 1995), and E3405Q (Fisher et al. 1999).

In this study, we describe the results obtained in a group of 27 Moroccan patients with a clinical diagnosis 
of $\mathrm{FH}$, and report for the first time the molecular changes in the LDLR gene likely to cause $\mathrm{FH}$ in Moroccans. For the purposes of this study, the LDLR gene was screened by PCR-SSCP analysis, DNA sequencing, and Southern blot analysis. In addition, the apoB gene was screened for the presence of the R3500Q and $\mathrm{R} 3531 \mathrm{C}$ mutations by PCR and restriction enzyme digestion analysis.

\section{Materials and methods}

Patients

All patients gave their informed consent prior to inclusion in the study. Eight Moroccan probands with clinical and biochemical features of FH from eight unrelated families were recruited from the Departments of Endocrinology and Metabolic Disorders at the University Hospitals of Casablanca and Rabat. The diagnostic criteria for FH probands were a high total serum cholesterol $(>290$ $\mathrm{mg} / \mathrm{dl}$ ), a family history of hypercholesterolemia (at least two affected first-degree relatives), and premature coronary disease, with the presence of arcus cornealis, xanthomas, or xanthelasmas. When members of these families were available, we performed a clinical and biochemical evaluation of $\mathrm{FH}$ in relatives and a co-segregation study of the disease and the identified mutation. In total, the study sample comprised $27 \mathrm{FH}$ patients, classified as 20 heterozygotes and seven homozygotes on the basis of clinical and biochemical data (Table 1).

Lipid measurements

Venous blood samples from fasting patients were drawn and serum was isolated after centrifugation at $4^{\circ} \mathrm{C}$ for $15 \mathrm{~min}$; serum total cholesterol (TC), triglycerides (TG), and high-density lipoprotein cholesterol (C-HDL) were then measured. TC and TG were analyzed by enzymatic methods (Boehringer Mannheim FRG). C-HDL was enzymatically determined by separating HDL from the plasma by precipitation of the (LDL + VLDL) fraction with a phosphotungstic acid $/ \mathrm{MgCl}_{2}$ solution (Boehringer Mannheim FRG). Serum LDL cholesterol was calculated according to the Friedewald formula (Friedewald et al. 1972).
DNA analysis

Genomic DNA was isolated from EDTA whole blood samples using a salting-out procedure (Miller et al. 1988).

DNA amplification, SSCP, and DNA sequencing The promoter and exon 4 were directly sequenced and the rest of the exons of the LDLR gene were screened for the presence of small variations by PCR-SSCP analysis. Amplification of the selected LDLR segments was performed individually by polymerase chain reaction (PCR) using an optimized set of oligonucleotide primers (Hobbs et al. 1992; Jensen et al. 1996) and PCR reaction conditions. For the SSCP analysis, electrophoresis was carried out in a horizontal minigel (Gene Gel Excel 12.5/24 Kit) system (Gene Phor) at $400 \mathrm{~V}$ for $15 \mathrm{~min}$ and then at $600 \mathrm{~V}$ for $1 \mathrm{~h}$ at $5-12^{\circ} \mathrm{C}$. After the electrophoresis, DNA bands were detected by silver stain. The direct sequencing of the promoter, exon 4 , and the fragments showing an altered SSCP pattern was performed in both directions by capillary electrophoresis in an ABI PRISM 310 Genetic Analyzer. Nucleotide positions and variations were numbered as suggested by Yamamoto et al. (1984).

For the apoB gene, the screening for mutations R3500Q and R3531C was performed by PCR-mediated, site-directed mutagenesis and double restriction of a unique PCR product (Rabès et al. 1997).

Southern blot analysis The LDLR gene was analysed by Southern blot for the presence of large rearrangements. Genomic DNA

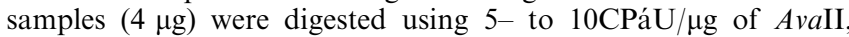
$P v u \mathrm{II}, E c o$ RI, and StuI, separated by agarose gel electrophoresis $0.8 \%$, transferred to nylon membranes, and hybridized successively with two ${ }^{32} \mathrm{P}$-labelled LDLR cDNA probes covering exons $1-10$ and exons $10-18$.

\section{Confirmation of variations in the LDLR gene}

To confirm the existence of variations that create or abolish a given natural restriction site, a rapid PCR-based DNA analysis was performed. Briefly, PCR products of the corresponding exon were digested with the relevant restriction enzymes (according to the manufacturer's instructions), electrophoresed on $2 \%$ agarose or $8 \%$ polyacrylamide gel, stained with ethidium bromide, and examined under UV illumination.

Table 1 Clinical and biochemical features of FH Moroccan probands

\begin{tabular}{|c|c|c|c|c|c|c|c|c|c|c|}
\hline $\begin{array}{l}\text { Proband } \\
\text { identification }\end{array}$ & Sex & $\begin{array}{l}\text { Age } \\
\text { (yrs) }\end{array}$ & $\begin{array}{l}\mathrm{TC} \\
(\mathrm{mg} / \mathrm{dl})^{\mathrm{a}}\end{array}$ & $\begin{array}{l}\text { C-HDL } \\
(\mathrm{mg} / \mathrm{dl})^{\mathrm{a}}\end{array}$ & $\begin{array}{l}\text { C-LDL } \\
(\mathrm{mg} / \mathrm{dl})^{\mathrm{a}}\end{array}$ & $\begin{array}{l}\mathrm{TG} \\
(\mathrm{mg} / \mathrm{dl})^{\mathrm{a}}\end{array}$ & EVLD & PCD & $\begin{array}{l}\mathrm{HC} \text { and/or } \\
\mathrm{PCD} \\
\text { antecedents }\end{array}$ & $\begin{array}{l}\text { No. of proband } \\
\text { relatives }\end{array}$ \\
\hline \multicolumn{11}{|l|}{ Heterozygotes } \\
\hline $1 \mathrm{M}$ & $\mathrm{M}$ & 40 & 300 & $\mathrm{ND}$ & ND & ND & No & No & Yes & $\begin{array}{l}2 \text { homozygotes, } \\
2 \text { heterozygotes }\end{array}$ \\
\hline $\mathrm{BA}$ & M & 47 & $320(207)$ & ND (62) & ND (119) & ND (132) & No & No & Yes & - \\
\hline B & M & 10 & 639 & 28 & 572 & 196 & $\mathrm{X}, \mathrm{TX}, \mathrm{AC}, \mathrm{CX}$ & Yes & Yes & 1 heterozygous \\
\hline $12 \mathrm{M}$ & $\mathrm{F}$ & 23 & 625 & 37 & 569 & 95 & $\mathrm{X}, \mathrm{TX}, \mathrm{AC}, \mathrm{CX}$ & Yes & Yes & $\begin{array}{l}1 \text { homozygous, } \\
2 \text { heterozygotes }\end{array}$ \\
\hline $18 \mathrm{M}$ & $\mathrm{F}$ & 24 & 458 & 47 & 397 & 64 & X, TX, CX & Yes & Yes & - \\
\hline $10 \mathrm{M}$ & $\mathrm{F}$ & 18 & 600 & 38 & 536 & 131 & $\mathrm{X}, \mathrm{TX}, \mathrm{CX}$ & Yes & Yes & 1 heterozygous \\
\hline
\end{tabular}

TC, Total cholesterol; C-HDL, HDL cholesterol; C-LDL, LDL cholesterol; TG, trigycerides; EVLD,extravascular lipid deposits; HC, hypercholesterolemia; PCD, premature coronary disease; X, xanthelasma; TX, tendon xanthomas; CX, cutaneous xanthomas; AC, arcuscornealis

${ }^{\mathrm{a}}$ The values in parentheses correspond to values after lipid-lowering treatment 


\section{Results and discussion}

Clinical and biochemical features of the probands are shown in Table 1. The mean serum total cholesterol level was 309 and 580CPámg/dl for the heterozygous and the homozygous probands, respectively, without lipid-lowering drug therapy.

It is important to note that in our country there is no specialized consultation for dyslipemia patients. Generally, FH patients are seen by cardiologists when cardiovascular complications appear, but the disease's etiology is not always investigated. This could explain the low number of FH patients recruited in our sample.

In this study, our aim was to obtain a preliminary molecular spectrum of the genetic defects causing FH in Morocco. For this purpose, we collected DNA from eight probands belonging to eight unrelated families and from 19 identified FH members of these families. All the probands were screened for $\mathrm{R} 3500 \mathrm{Q}$ and $\mathrm{R} 3531 \mathrm{C} \mathrm{mu-}$ tations in the apoB gene by PCR-mediated, site-directed mutagenesis. Neither of these FDB-causing mutations were found in our sample. Because we screened the apoB gene only for the R3500Q and R3531C mutations and did not analyse it for other possible mutations, we cannot definitively rule out the presence in our sample of FDB patients with an FH phenotype.

Concerning the analysis of the LDLR gene, we performed the molecular search for mutations in the promoter region and the 18 exons of this gene. Using PCR-SSCP analysis and DNA sequencing, we detected nine variations in the LDLR gene. These included five missense mutations (C113R, G266C, A370T, P664L, C690S) (Table 2) and four silent sequence variations (C6C, L554L, N570N, V632V). Four of the aforementioned missense mutations, C113R, A370T, P664L, and C690S, have been described previously in other populations.

The A370T variation has been shown not to be associated with FH and appears to be a genetic polymorphism in the Caucasian population (Gudnason et al. 1995; Weiss et al. 1998). In our sample, we found this polymorphism in two families in whom it segregated, indicating that this genetic variation is not specific to the Caucasian population.

The P664L mutation has been demonstrated to be causative of FH (Soutar et al. 1989). We found this mutation in one compound heterozygous proband. The proband's brother does not carry this mutation. We have not yet found the other allele defect in these $\mathrm{FH}$ patients. At present, we do not know the exact contribution of the P664L mutation to the FH phenotype of the compound heterozygous proband.

The C113R mutation has been described in Dutch and German patients (Heath et al. 2001; Nauck et al. 2001; Fouchier et al. 2001) and C690S in the Dutch population only (Fouchier et al. 2001). It is interesting to note that 300,000 individuals living in the Netherlands are Moroccans, and the finding of these two mutations in our population could be accounted for by the important flux migration to this country. Further investigations must be done to address this issue.

The G266C missense mutation is novel mutation never previously reported, and it has not been found in a sample of 56 healthy Moroccan controls. This mutation is located in repeat VII of the ligand binding domain and changes a conserved glycine to a cysteine. In fact, this domain includes seven repeats and this conserved glycine is found in repeats I, III, V, VI, and VII. This change could interfere with the disulfide bonds pattern, which confers to the receptor an extremely stable structure essential for the protection of the molecule from degradation when it is recycled several times. On the other hand, it has been established that all the repeat sequences from II to VII of the first domain are essential to the optimal binding of apo B in LDL, and replacement of a conserved neutral amino acid (glycine) by an amino acid with a polar residue (cysteine) in repeat VII could also have an effect on apo B binding (Lestavel and Fruchart 1994). The effect of this novel mutation on the functional activity of LDLR is hypothetical. Unfortunately, we were not able to demonstrate the co-segregation of the G266C mutation with the FH phenotype, because family relatives of the proband were not available for genetic testing.

The frequent four silent polymorphisms C6C, L554L, $\mathrm{N} 570 \mathrm{~N}$, and V632V were also found in our sample. These polymorphisms were found in more than one individual from different families: $\mathrm{C} 6 \mathrm{C}$ was found in one family, N570N in five families, and L554L and $\mathrm{V} 632 \mathrm{~V}$ in two families.

Southern blot analysis allowed the detection of two different novel partial deletions in two probands, $8 \mathrm{M}$ and $12 \mathrm{M}$. Since these deletions have never been reported

Table 2 Missense mutations found in the LDLR gene in Moroccan FH patients

\begin{tabular}{|c|c|c|c|c|c|}
\hline Proband ID & Location & Event & Variation name & Confirmed using ${ }^{\mathrm{b}}$ & Genotype \\
\hline $6 \mathrm{M}$ & Exon 4 & $400 \mathrm{~T} \rightarrow \mathrm{C}$ & C113R & AvaII + & Htz \\
\hline $18 \mathrm{M}$ & Exon 6 & $859 \mathrm{G} \rightarrow \mathrm{T}$ & G266C & AluI + & $\mathrm{Hmz}$ \\
\hline $8 \mathrm{M}, \mathrm{BA}$ & Exon 8 & $1171 \mathrm{G} \rightarrow \mathrm{A}^{\mathrm{a}}$ & A370T & StuI - & $\mathrm{Htz}, \mathrm{Hmz}$ \\
\hline $10 \mathrm{M}$ & Exon 14 & $2054 \mathrm{G} \rightarrow \mathrm{C}$ & P664L & PstI + & $\mathrm{Htz} \mathrm{C}$ \\
\hline $1 \mathrm{M}$ & Exon 14 & $2132 \mathrm{C} \rightarrow \mathrm{T}$ & C690S & ItaI - & $\mathrm{Htz}$ \\
\hline
\end{tabular}

ID, Identification; ND, not determined; Htz, heterozygous; Hmz, homozygous; Htz C, compound heterozygous

${ }^{a}$ Polymorphism not associated with FH

${ }^{\mathrm{b}}+$, variation creates restriction site; - , variation destroys restriction site 
previously, we have designated these mutations $\mathrm{FH}$ Morocco-1 and FH Morocco-2. Southern blotting of the DNA sample from proband $8 \mathrm{M}$ showed a heterozygous $\sim 0$.9-kb deletion (FH Morocco-1) situated between the $3^{\prime}$ end of intron 1 (350 bp downstream from exon 2) and the $5^{\prime}$ end of exon 3 (28 bp). The precise limits of this small deletion must be further investigated to assess the potential disease-causing impact of this mutation.

After digestion with EcoRI, the hybridization of the $12 \mathrm{M}$ proband's DNA with cDNA probes exon 1-10 showed the loss of the $\sim 9.6-\mathrm{kb}$ fragment and an additional $\sim 3.2-\mathrm{kb}$ fragment. This preliminary screening suggested that $12 \mathrm{M}$ was homozygous for a gross deletion (FH Morocco-2), which eliminates exons 2, 3, and 4 and is expected to be the disease-causing mutation.

The molecular status of FH in Morocco has been unknown until now. In this study, we have partially clarified the mutational spectrum of LDLR gene defects in our sample of eight unrelated families, which seems to be heterogeneous. The mutational analysis predicted the potential disease-causing impact of G266C, C113R, and C690S missense mutations in three probands $(18 \mathrm{M}, 6 \mathrm{M}$, $1 \mathrm{M})$ and one partial deletion in one proband (8M). Prediction of the impact of the other rearrangement, found in $12 \mathrm{M}$ (deletion of $\sim 0.9 \mathrm{~kb}$ ), is not possible until the exonic involvement is known. In proband $10 \mathrm{M}$, we cannot attribute the $\mathrm{FH}$ phenotype only to the $\mathrm{P} 664 \mathrm{~L}$ mutation until we have identified the other allele defects present in this family. Therefore, molecular identification of mutant alleles was possible in $75 \%$ of all cases. For the remaining cases, the molecular basis of $\mathrm{FH}$ remains unknown. This can be explained by the SSCP technique limits to detect all single base changes (Humphries et al. 1997), or by the intervention of other genes causing an FH-like phenotype.

Before any conclusions can be drawn about the molecular status of FH in Morocco, a larger number of clinically diagnosed FH patients will have to be tested.

Acknowledgements We thank the many clinicians who provided the blood samples and clinical data of their FH patients. We also thank Dr. A. Cenarro for critical reading of the manuscript.

\section{References}

Fisher E, Scharnagl H, Hoffmann MM, et al. (1999) Mutations in the apolipoprotein (apo) B-100 receptor-binding region: detection of apo B-100 (Arg3500CP ÆTrp) associated with two new haplotype and evidence that apo B-100 (Glu3405CPÆGln) diminishes receptor-mediated uptake of LDL. Clin Chem 45:1026-1038

Fouchier SW, Defesche JC, Umans-Eckenhausen MA, Kastelein JJ (2001) The molecular basis of hypercholesterolemia in the Netherlands. Hum Genet 109:602-615

Friedewald WT, Levy FI, Fredrickson DS (1972) Estimation of the concentration of the low density lipoprotein cholesterol in plasma without use of the preparative ultracentrifuge. Clin Chem 18:499-509

Gaffney D, Reid JM, Cameron IM, Vass K, Caslake M, Sheperd J, Packard CJ (1995) Independent mutations at codon 3500 of the apolipoprotein B gene are associated with hyperlipidaemia. Arterioscler Thromb Vasc 15:1025-1029

Goldstein JL, Hobbs HH, Brown MS (1995) Familial hypercholesterolemia. In: Scriver CR, Beaudet AL, Sly W, Valle D (eds) The metabolic and molecular bases of inherited disease, 7th edn. McGraw-Hill, New York, pp 1981-2030

Gudnason V, Patel D, Sun X-M, Humphries S, Soutar AK, Knight BL (1995) Effect of the StuI polymorphism in the LDL receptor gene (Ala370 to Thr) on lipid levels in healthy individuals. Clin Genet 47:68-74

Haddad L, Day IN, Hunt S, Williams RR, Humphries SE, Hopkins PN (1999) LDLR, non-APOB kindred. J Lipid Res 40:1113-1122

Heath KE, Gahan M, Whittal RA, Humphries SE (2001) Lowdensity lipoprotein receptor gene (LDLR) world-wide web site in familial hypercholesterolemia: update, new features and mutation analysis. Atherosclerosis 154:243-246

Hobbs H, Brown MS, Goldstein JL (1992) Molecular genetics of the LDL receptor gene in familial hypercholesterolemia. Hum Mutat 1:4445-4466

Humphries SE, Gudnason V, Whittall R (1997) Single-strand conformation polymorphism analysis with high throughput modifications, and its use in mutation detection in familial hypercholesterolemia. Clin Chem 43:427-435

Hunt SC, Hopkins PN, Bulka K, McDermott MT, Thorne TL, Wardell BB, Bowen BR, Ballinger DG, Skolnick MH, Samuels ME (2000) Genetic localization to chromosome 1p32 of the third locus for familial hypercholesterolemia in Utah kindred. Arterioscler Thromb Vasc Biol 20:1089-1093

Jensen HK, Jensen LG, Hansen PS, Faergeman O, Gregersen N (1996) High sensitivity of the single-strand conformation polymorphism method for detection of sequence variations in the LDL receptor gene validated by DNA sequence. Clin Chem 42:1140-1146

Leren TP, Tonstad S, Gudersen KE, Bakken KS, Rodningen OK, Sundvold H, Ose L, Berg K (1997) Molecular genetics of familial hypercholesterolemia in Norway. J Intern Med 241: 185-194

Lestavel S, Fruchart JC (1994) Lipoprotein receptors. Cell Mol Biol 40:461-481

Miller SA, Dykes DD, Polesky HF (1988) A simple salting out procedure for extracting DNA from nucleated cells. Nucleic Acids Res 16:1215

Myant NB (1993) Familial defective apolipoprotein B-100: a review, including some comparisons with familial hypercholesterolemia. Atherosclerosis 104:1-18

Nauck MS, Köster W, Dörfer K, Eckes J, Scharnagl H, Gierens H, Nissen H, Nauck MA, Wieland H, MCPñrz W (2001) Identification of recurrent and novel mutations in the LDL receptor gene in German patients with familial hypercholesterolemia. Hum Mutat 18:165-166

Norman D, Sun XM, Bourbon M, Knight BL, Naoumova RP, Soutar AK (1999) Characterization of a novel cellular defect in patients with phenotypic homozygous familial hypercholesterolemia. J Clin Invest 104:619-628

Pullinger CR, Hennessy LK, Chatterton JE, Liu W, Love JA, Mendel CM, Frost PH, Malloy MJ, Schumaker VN, Kane JP (1995) FDB: identification of a new mutation that decrease LDL-receptor binding affinity. J Clin Invest 95:1225-1234

Rabès JP, Varret M, Saint-Jore B, Erlich D, Jondeau G, Giraudet P, Junien C, Boileau C (1997) Familial ligand-defective apolipoprotein B-100: simultaneous detection of the Arg3500CPÆGln and Arg3531CPÆCys mutations in a French population. Hum Mut 10:160-163

Soria LF, Ludwig EH, Clarke HRG, Vega GL, Grundy SM, McCarty BJ (1989) Association between a specific apo B mutation and familial defective apoB100. Proc Natl Acad Sci U S A 86:587-591

Soutar AK, Knight BL, Patel DD (1989) Identification of a point mutation in growth factor receptor $\mathrm{C}$ of the low density lipoprotein-receptor gene in a patient with homozygous familial 
hypercholesterolemia that affects ligand binding and intracellular movement of receptors. Proc Natl Acad Sci U S A $86: 4166-4170$

Varret M, Rabès JP, Kotze MJ, Baron H, Cenarro A, Descamps O, Ebhardt M, Nondelijn JC, Kostner GM, Miyake Y, Pocovi M, Shmidt H, Schuster H, Stuhrmann M, Yamamura T, Junien C, Beroud C, Boileau C (1998) LDLR database (second edition): new additions to the database and the software, and results of the first molecular analysis. Nucleic Acids Res 26:248-252

Varret M, Rabès JP, Saint-Jore B, Cenarro A, Marinoni JC, Civeira F, Devillers M, Krempf, Culon M, Thiart R, Kotze MJ,
Schmidt H, Buzzi JC, Kostner GM, Bertoleni S, Rosa A, farnier M, Martinez M, Junien C, Boileau C (1999) A third major locus for autosomal dominant hypercholesterolemia maps to 1p34.1-32. Am J Human Gene 64:1378-1387

Weiss N, Binder G, Keller C (1998) Heterozygosity for the missense mutation Ala370CP $Æ T h r$ in exon 8 of the low density lipoprotein receptor gene does not cause hypercholesterolemia. Eur J Med Res 3:20-24

Yamamoto T, Davis CG, Brown MS, Schneider WJ, Casey ML, Goldstein JL, Russell DW (1984) The human LDL receptor: a cysteine-rich protein with multiple Alu sequences in its mRNA. Cell 39:27-38 